\title{
FORGÁCSOLÓ SZERSZÁM TERVEZÉSE GOLYÓSANYA MENETESZTERGÁLÁSÁHOZ
}

\author{
Kiss Dániel \\ egyetemi tanársegéd, Miskolci Egyetem, Szerszámgépek Intézeti Tanszéke \\ 3515 Miskolc, Miskolc-Egyetemváros, e-mail: kiss.daniel@uni-miskolc.hu \\ Mihályi Gergő \\ tervezömérnök, BekoMold Kft. \\ 1037 Budapest, Bojtár u. 74., e-mail: mihalyi.gergo85@gmail.com
}

\begin{abstract}
Absztrakt
A cikk a golyósanya menetfelületének különbözö megmunkálási lehetöségeit ismerteti. A nagy menetemelkedésü golyósanyák forgácsolással történö megmunkálásának egyik hátránya, hogy módositott szerszámprofil elöállitása szükséges, hogy elkerüljük a szerszámtartó és a munkadarab ütközését. Profilos forgácsolólapkákkal azonban lehetséges a golyósanya menetprofiljának elöállitása esztergálással. A technológia alkalmazhatóságát a koncepcionális tervek alapján készült szerszámmal és kísérleti megmunkálással igazoljuk, amelyek eredményeit a cikk végén ismertetjük.
\end{abstract}

Kulcsszavak: esztergálás, szerszám, golyósanya

\section{Abstract}

This article shows different machining methods of the ball nut thread. A disadvantage of machining high pitch ball nuts by grinding process is to produce a modified tool profile to avoid collision between the tool holder and workpiece. However, by using profiled lathe inserts, it is possible to produce thread profile of the ball nut. The applicability of method is verified by tooling and experimental machining based on conceptual designs, the results are described at the end of article.

Keywords: turning, tool, ball nut

\section{Bevezetés}

A golyósanyák forgácsolására az alkatrész hőkezeltségi állapotától függően igen szük forgácsolási technológia alkalmas [1], [2]. Lágyított állapotban történő forgácsolásnál az esztergálást (1. ábra) és a marást (2. ábra) alkalmazzák edzett, betétedzett anyák befejezö megmunkálására a köszörülést.

A golyósanya élettaramát figyelembe véve a martenzites szövetszerkezet terjedt el. A martenzites szövetszerkezet előnye a nagy keménység és kopásállóság, azonban ez a forgácsolást megnehezíti. Emiatt alkalmazzák a profilköszörülést befejező megmunkálásként a hagyományos gyártástechnológiai műveleteknél, ami bizonyos technológiai korlátok között (anya belső átmérö, menethossz) igen jól alkalmazható. Ezen tanulmány célja, hogy a keményesztergálás lehetőségét megvizsgálja a gótikus-profilú anyamenetek edzett/betétedzett állapotban történő megmunkálásra.

Nagy menetemelkedésű golyósanyáknál a menetemelkedési szög miatt torzított profilú szerszámot kell tervezni. A profiltorzulás elkerülésének érdekében esztergáló- és marószerszámoknál is hátszög kompenzációval oldják meg ezt a problémát. Az alkalmazott (müködő) hátszög nagyságát az anyagminőség forgácsolásához szükséges minimális hátszög és a golyósanya legkisebb átméröjére 
számított spirálemelkedési szög összegeként kapjuk meg. Emiatt nem alkalmazható a marási technológia hatékonyan szerszámbedöntés nélkül edzett állapotban történő megmunkálásnál, mivel a nagy hátszögek eredöje a szerszám élkörnyezetét károsan befolyásolja. További hátrány, hogy bedöntés nélkül csak is kizárólag egy élü maró jöhet számításba, mivel a további maró élek elforgácsolnák a megmunkálatlan felületeket az előtolás irányban.

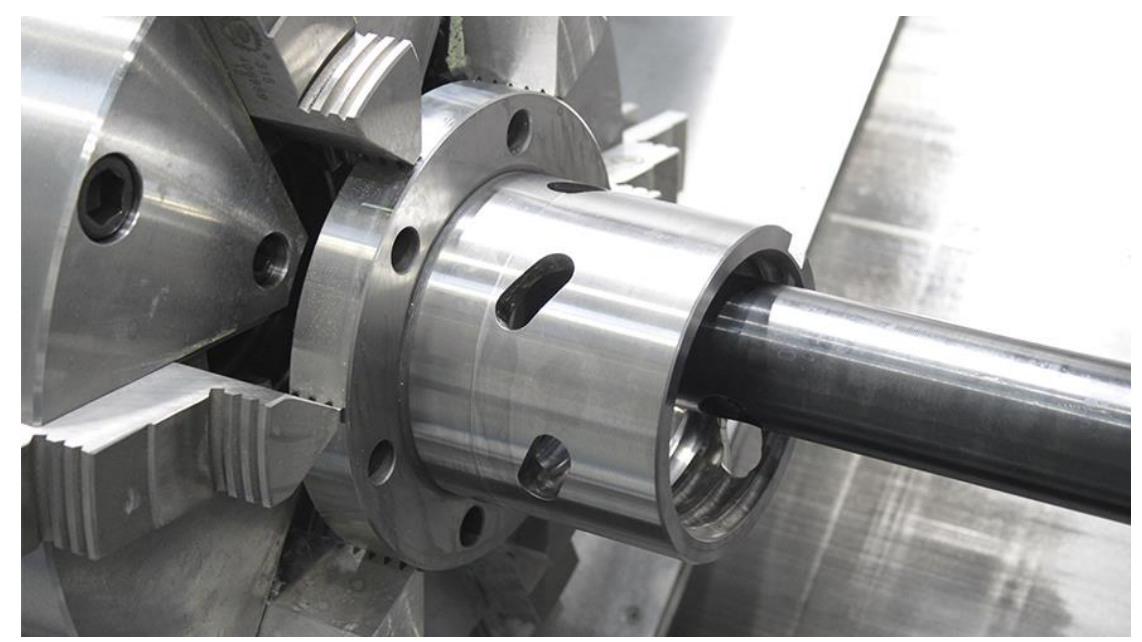

1. ábra. Golyósanya menetesztergálása [3]
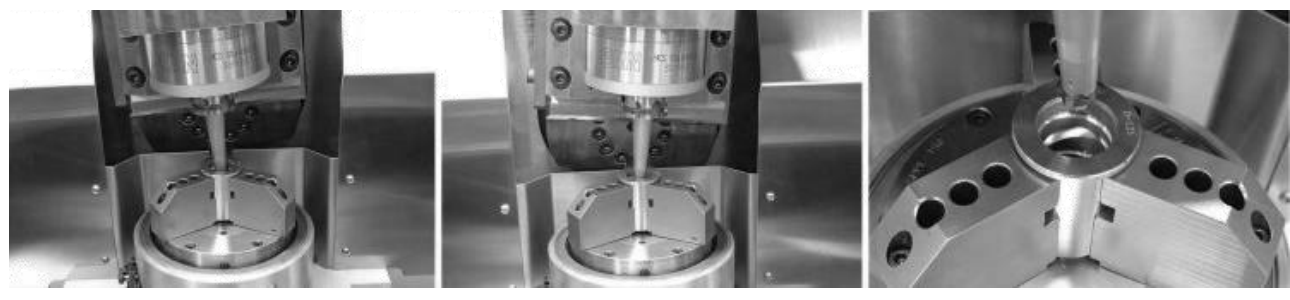

2. ábra. Golyósanya menetmarása [4]

Amennyiben a megmunkáláskor a marószerszámot ütközés nélkül bedönthetjük többélủ szerszám is alkalmas a forgácsoláshoz. Előnye közt szerepel, hogy a több él nagyobb termelékenységet jelent, viszont az élek profilját nem lehet pontosan összehangolni, ezért nagy pontosságú menetek elő́llítására nem alkalmas. Ez az eljárás csak nagyoláshoz alkalmazható termelékenyen, mert profilsimításkor a kapcsolószám kisebb mint 1, így egy időben mindig csak egy él képes forgácsolni. A köszörülés technológiai korlátja a maximálisan alkalmazható golyósanya belső átmérője, a köszörükorong átméröje és a golyósanya menethosszából adódik, mivel a korongot axiális irányban, a menetemelkedés szögének megfelelően be kell dönteni [5]-[7]. A kis- és közepes menetemelkedésü anyaváltozatokkal ellentétben az edzett profil köszörülése nem valósítható meg nagy menethossznál, aminek két fö oka van. A nagy menethosszból és a nagy menetemelkedésből eredő menetemelkedési szög a szerszámtartó ütközését eredményezi a magfurat átméröjén. A másik fö probléma a menetemelkedési szögböl ered, minél nagyobb mértékben kell megdönteni egy profilos szerszámot, annál nagyobb a profiltorzulás mértéke. A korongdöntési szög értékét a köszörükorong átméröje is befolyásolja, ami hatással van a szerszám fordulatszámára. A kisebb korongátmérő hátránya, hogy 
nagy fordulatszám alkalmazása mellett képes technológiailag jól üzemelni, valamint a korongdöntési szöget csökkenti. Az 1. táblázat az adott technológiák alkalmazhatóságának korlátait tartalmazza golyósorsóknál a 20-80 mm-es tartományban. A fenti táblázatban jól megfigyelhető, hogy a hengerléssel készült előgyártmányok föként a táblázat baloldali, valamint az alsó táblázati régiókban érvényesülnek a legjobban. Ennek a fő oka a képlékeny alakítás erőszükséglete lehet, mivel a növekvő átmérővel a golyópályák mélysége is növekszik. A köszörülés technológiai korlátait a menetemelkedés korlátozza és a hozzátartozó menetemelkedési szög, mivel a köszörükorongot a menetemelkedési szögnek megfelelően be kell dönteni. A cikkben a legfeljebb $6^{\circ}$ menetemelkedési szöggel rendelkező golyósanyákat vizsgáljuk, ugyanis ezen paraméterrel rendelkező alkatrészeknél az esztergálási, marási, valamint a köszörülési technológiák is alkalmasak a megmunkálásra.

Az iparban szerzett tapasztalatok alapján az esztergálás felső határértéke golyósanya gyártásakor megközelítőleg $P / D \approx 0,63$. A vizsgált esetben ez a hányad kisebb $(\approx 0,48)$, de a korábbi tapasztalatokkal ellentétben jóval nagyobb fogásmélység mellett kellett a forgácsolást végezni.

1. táblázat. Golyósorsók megmunkálási technológiája a méretek függvényében

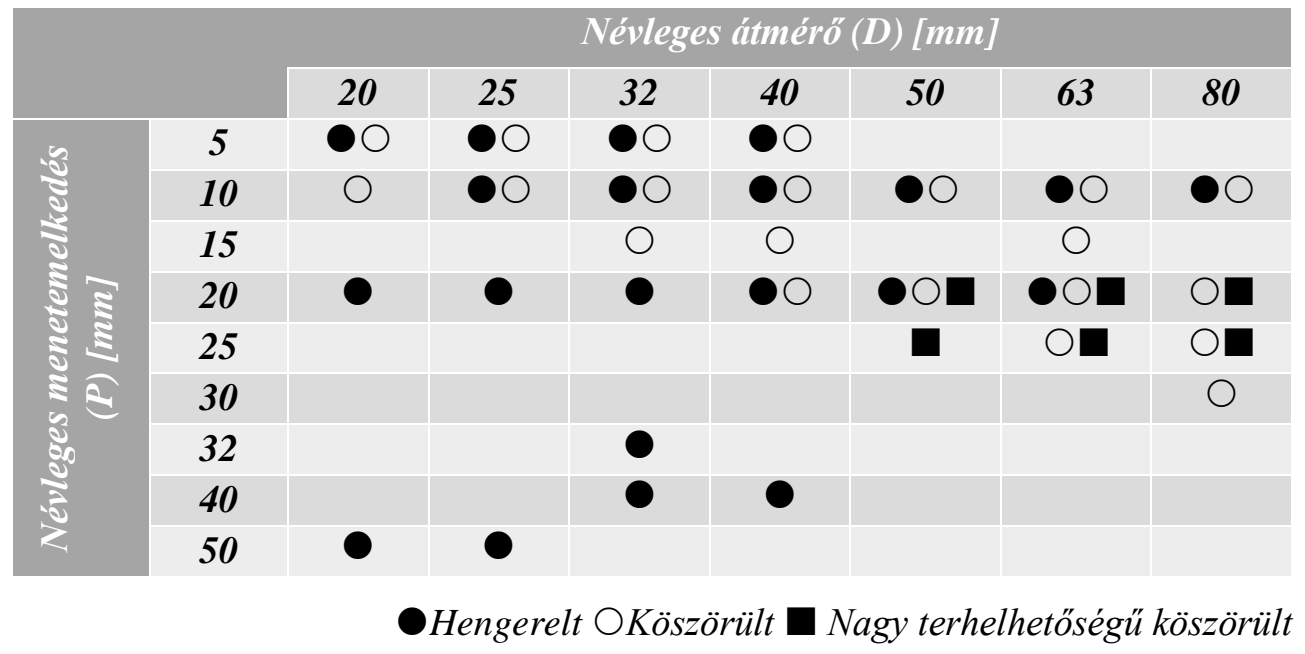

Az egyes technológiai korlátok nem csak a megmunkálás erő, valamint teljesítmény szükségletéhez köthetők, hanem a szerszám gyárthatóságához is. A forgácsoló lapkák gyártása nem a forgácsolásban eltöltött pozíciójához tartozó szerszámtestben történik, hanem úgynevezett dönthetőségét tekintve $\gamma_{\text {radialis }}=0^{\circ}$, vagy $\gamma_{\text {axiális }}=0^{\circ}$ szerszámtestben, tehát torzított profillal készülnek a szerszámlapkák. Az elsődleges hátszög köszörülési korlátja hozzávetölegesen $30^{\circ}$, de szikraforgácsolással és megfelelö

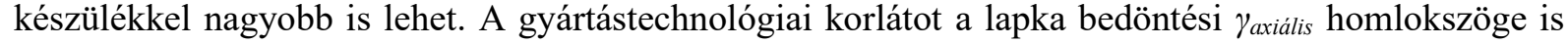
korlátozza, mivel a lapka hasznos profilszélessége annak bedöntésével csökken, ami az elöírt profil gyárthatóságát korlátozza.

Az irodalmak eltérnek a keményforgácsolás technológiájának definiálásában, de kijelenthető, hogy az 55-64HRC keménységgel rendelkező acéloknál beszélhetünk kemény forgácsolásról. A technológia velejárója, hogy a nagy keménység miatt nem alakul ki a nyírási sík és a forgácselemek egy repedés megindulásával szakadnak le a munkadarab felületéről, miközben jelentős erőhatások ébrednek a lágyított állapotú forgácsoláshoz képest.

A 3. ábra egy golyósanya megmunkálási folyamatát mutatja keményesztergálás és köszörülés esetén. A különböző megmunkálási paramétereket és az elérhető pontosságokat a 2. táblázat ismerteti. 

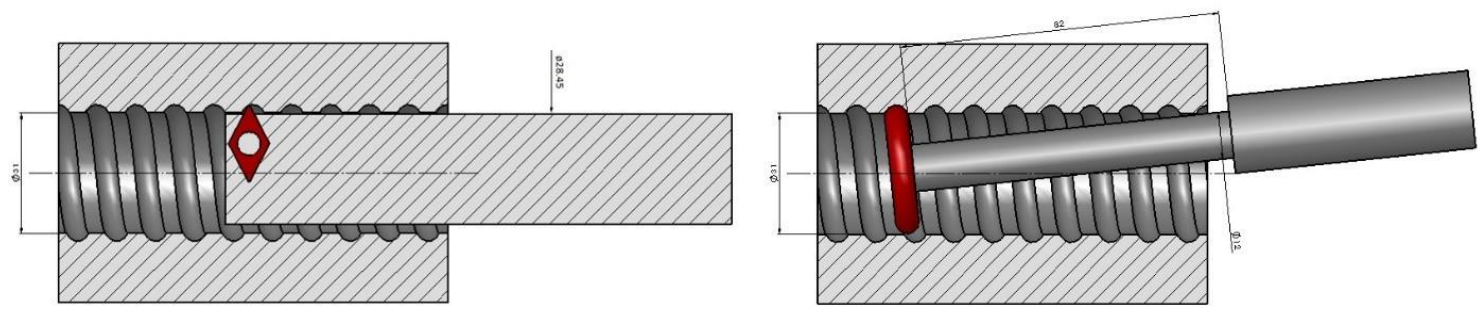

3. ábra. Golyósanya menetesztergálása (bal) és menetköszörülése (jobb) [8]

2. táblázat. Technológiai jellemzök menetesztergálás és menetköszörülés esetén

\begin{tabular}{|c|c|c|}
\hline & Meneteszatergálás & Menetköszörülés \\
\hline Anyagleválaszatás & $150-1500 \mathrm{~mm}^{3} / \mathrm{min}$ & $10-60 \mathrm{~mm}^{3} / \mathrm{min}$ \\
\hline Szerszám merevsége & $15-100 \mathrm{~N} / \mu \mathrm{m}$ & $0.1-8 N / \mu m$ \\
\hline Menetemelkedési hiba & $0.5-2 \mu m$ & $0.5 \mu m^{*}$ \\
\hline Felületi érdesség $R a$ & $0.2-0.5 \mu m$ & $0.1-0.4 \mu m^{*}$ \\
\hline Pontossági fokozat & IT $1-2$ & IT $1-5$ \\
\hline
\end{tabular}

A keményforgácsolás korai szakaszában befejező megmunkáláshoz a köszörülést használták. A köszörülés alkalmazásának egyik környezetvédelmi hátránya, hogy a köszörülés során a munkadarab anyagából és a köszörükorong komponenseiből úgynevezett „köszörüiszap” képződik. Ezért fejlesztették ki a $C B N / P C B N$ anyagminőséget, amelyet WIPER geometriával alkalmazva keményesztergálásnál a köszörült felületre jellemző felületi és mikrotopográfiai jellemzőket eredményez. A $C B N$ technológiának is vannak korlátai, ilyen például a keménység, azaz a $C B N$-t $48 H R C$ alatt nem gazdaságos használni. A CBN szerszámanyagot nagysorozatnál $60 H R C$ felett javasolt alkalmazni, ahol a megtérülés esélye nagyobb. A golyósanya gyártásához a $C B N$ technológia több technológiai problémát okoz. A vizsgált alkatrésznél a golyósanya profilja túl széles, így a $C B N$ betét forrasztásakor fellépő nagy hőmérséklet különbség miatt a keményfém ágy összeroppanthatja a $C B N$ betétet, így a $C B N$ bevonati rétegek alkalmazása lenne célszerü. Léteznek bór tartalmú bevonatok, amelyek szintén nagy keménységüek, mint pl. $T_{2} B_{2}$ vagy $T i B N$ [9]. További probléma, hogy a $C B N$ betéteket nagy forgácsolósebességeken lehet használni, szemben a menetvágás technológiájával. Így a menetvágó ciklusok a kis forgácsolósebességek és nagy előtolások miatt nem alkalmazhatók. Másik megoldás lehet az OERLIKON BALZERS ALDURA fantázianévvel ellátott bevonat típus, amelyet kifejezetten nagy keménységü anyagminőségek megmunkálásához javasolnak. Keményesztergálás területéhez sorolhatók a kerámia lapkás szerszámok. A szilícium-nitrid $\left(\mathrm{Si}_{3} \mathrm{~N}_{4}\right)$ az egyik ismert kerámia, amely igen elönyösen alkalmazható megszakított forgácsoláshoz, mivel törőszilárdsága még a $C B N$-ét is meghaladja. A szilícium-nitrid emellett nagy oxidációs ellenállással rendelkezik és nagyobb forgácsolósebességeknél gazdaságos az alkalmazása. Vastartalmú fémek nagyolási stratégiákhoz kifejezetten alkalmas, valamint használata nagy forgácsolósebességeknél és közepes volumenü gyártásnál gazdaságosabb. A javasolt munkadarab keménység korlátja $50-55 H R C$, költség szempontjából a keményfém lapkák és a $C B N$ betétes lapkák között helyezkedik el. 
Folytonos felületek forgácsolásához (simítási technológiákhoz) használatos az alumínium-oxid $\left(\mathrm{Al}_{2} \mathrm{O}_{3}\right)$ kerámia, amit még nagyobb forgácsolósebesség tartományban érdemes használni, mint a szilícium-nitridet. Hasonlóan a szilícium-nitrid kerámiákhoz, az alumínium-oxid szintén nagy oxidációs ellenálló képességgel rendelkezik. Mindkét kerámiát csak szárazforgácsoláshoz ajánlják, mivel a hütés hatására a szerszámanyag elpattan. A nagy oxidációs ellenállással a többi szerszámanyaghoz képest kifejezetten a magasabb hőmérsékleti tartományokban hasznosul. A hagyományos keményfém lapkaminőségek is alkalmazhatóak kemény forgácsoláshoz, de alacsony forgácsolósebesség mellett és maximum 55HRC keménységig.

\section{Forgácsoló szerszám tervezése golyósanya menetesztergálásához}

A szerszám koncepcionális tervezése egy $D=50 \mathrm{~mm}$ névleges átmérőjü és $P=25 \mathrm{~mm}$ menetemelkedésü jellemző méretekkel adott golyósanyához lett elvégezve. A koncepcionális tervezéshez a CATIA V5R19 szoftvert alkalmaztuk, melynek eredményét a 4. ábra szemlélteti.

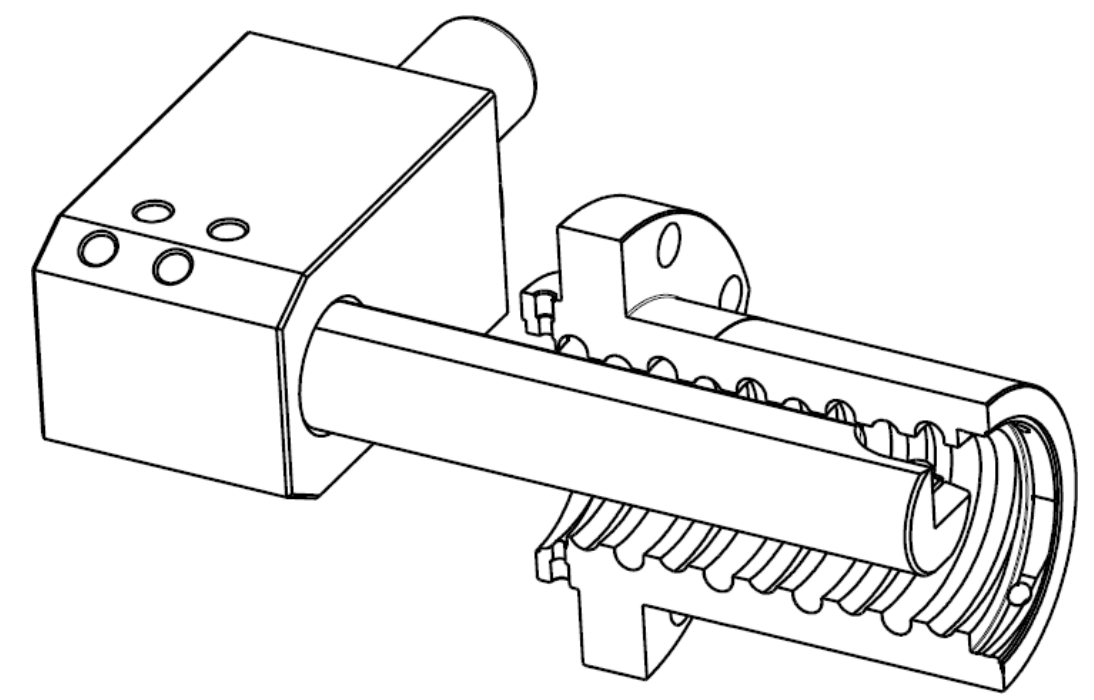

4. ábra. A menetesztergáló szerszám koncepcionális terve

A próbaforgácsoláshoz szükséges volt a megtervezett szerszámlapka és szerszámszár legyártása, melyeket az 5. ábra szemléltet.
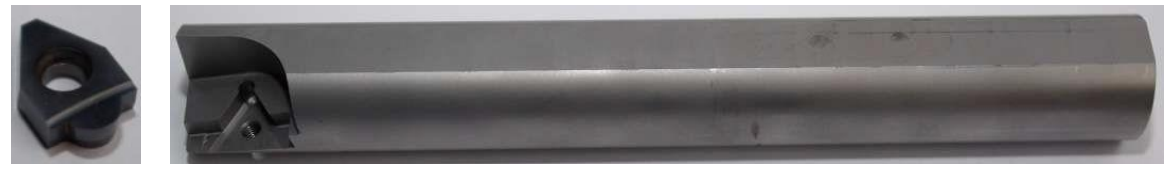

5. ábra. A legyártott forgácsolólapka és befogószár

A menetfelület kísérleti megmunkálásának vizsgálati feltételei:

- alkalmazott szerszámgép: DMG CTX Alpha 500 (vezérlő: SINUMERIK 840D),

- hütö-kenő folyadék alkalmazása a forgácsolás alatt,

- föorsó fordulatszáma: $n=180 \mathrm{~min}^{-1}$ (forgácsolási sebesség: $v_{c} \approx 30 \mathrm{~m} / \mathrm{min}$ ),

- elötolás: $f=25 \mathrm{~mm}$. 


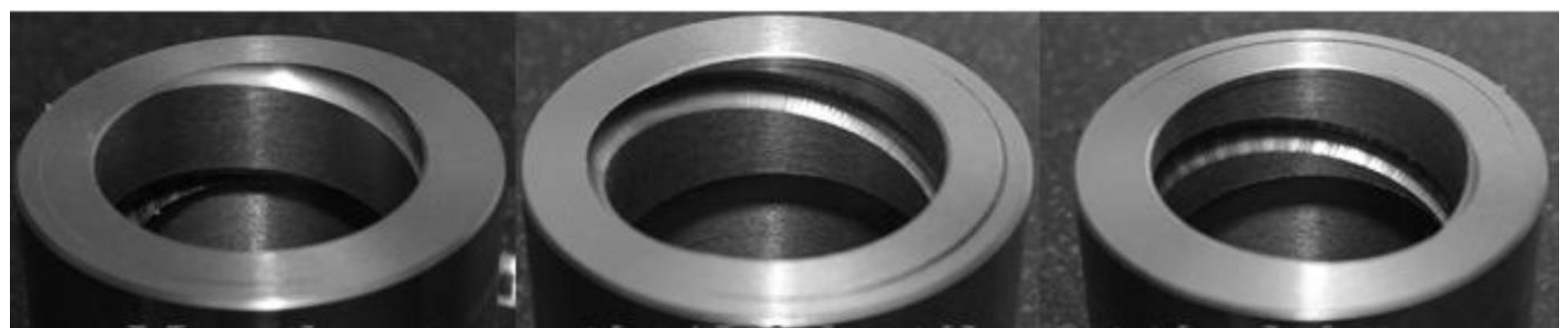

6. ábra. A próbaforgácsolás eredménye

A forgácsolásban résztvevő elemek öngerjesztési jelensége látható az előbbi. A forgácsolás kezdeti szakaszában, amikor még a lapka nem dolgozik a profil teljes keresztmetszetében a rezgések nem számottevőek. A profilszakasz teljes müködésével (a munkadarab megfogó felé haladva) a rezgések erősödnek és az öngerjesztés jelensége onnan érzékelhető, hogy a menethossz mentén fokozatosan mélyülnek a barázdák a munkadarab felületén. A kép baloldali részén a menet kezdete és a vége is megfigyelhetö összehasonlításképp. A fogásbalépéskor sima egyenletes a menetfelület, a kilépéskor azonban a felületi érdesség durvább. Az öngerjesztés ilyen jellegü megnyilvánulása a szerszámszán hibát is jelenthet.

\section{3. Összefoglalás}

A cikkben röviden összefoglaltuk a golyósanyák belső menetfelületének megmunkálására alkalmas gyártástechnológiai lehetőségeket. Az irodalmak és korábbi tapasztalatok alapján látható, hogy a golyópályák nagyoló forgácsolására elsősorban a lágy állapotban történő esztergálás és menetmarás alkalmas. Kísérleti megmunkálásra alkalmas szerszámozást terveztünk egy adott méretü golyósanya menetfelületének készítésére, ahol a megmunkálás eredményeit kiértékelve látható, hogy a megfelelő méretpontosság és felületi érdesség eléréséhez a hagyományos menetköszörülést és keményesztergálást célszerü választani, amennyiben a keményesztergáláshoz megfelelő merevségü és stabilitású megmunkálógép áll rendelkezésre.

\section{Köszönetnyilvánítás}

A cikkben ismertetett kutató munka az EFOP-3.6.1-16-2016-00011 jelü „Fiatalodó és Megújuló Egyetem - Innovatív Tudásváros - a Miskolci Egyetem intelligens szakosodást szolgáló intézményi fejlesztése" projekt részeként - a Széchenyi 2020 keretében - az Európai Unió támogatásával, az Európai Szociális Alap társfinanszírozásával valósul meg.

\section{Irodalom}

[1] Rech, J., Moisan, A.: Surface integrity in finish hard turning of case-hardened steels, International Journal of Machine Tools and Manufacture, 43 (5), (2003) pp. 543-550. https://doi.org/10.1016/S0890-6955(02)00141-4

[2] Bartarya, G., Choudhury, S.: State of the art in hard turning, International Journal of Machine Tools and Manufacture, 53 (1), (2012) pp. 1-14. https://doi.org/10.1016/j.ijmachtools.2011.08.019

[3] https://danobatgrinding.com/en/balls-screw-nut-machining (accessed: 15. September 2020)

[4] Introducing Drake GS: VTM-LM (brochure) 
[5] Harada, H., Kagiwada, T.: Grinding of high-lead and gothic-arc profile ball-nuts with free quill-inclination, Precis Eng. 28 (2), (2004) pp. 143-151. https://doi.org/10.1016/j.precisioneng.2003.07.003

[6] Hegedűs, Gy., Patkó, Gy., Takács, Gy.: Determination of tool profile for ballnut grinding by numerical methods, 2012 Proceedings of the $13^{\text {th }}$ International Conference on Tools, ICT 2012, ISBN:9789639988354

[7] Hegedüs, Gy.: Newton's method-based collision avoidance in a CAD environment on ball nut grinding, The International Journal of Advanced Manufacturing Technology, 2015. https://doi.org/10.1007/s00170-015-7796-5

[8] Shorter cycle times and fewer process steps for complex contours, all thanks to hard turning, Article- Hembrug Machine Tools, www.hembrug.com

[9] More, A., Jiang, W., Brown, W., Malshe, A.: Tool wear and machining performance of $C B N-$ TiN coated carbide inserts and PCBN compact inserts in turning AISI 4340 hardened steel, Journal of Materials Processing Technology, 180 (1-3), (2006) pp. 253-262.

https://doi.org/10.1016/j.jmatprotec.2006.06.013 